\title{
Effects of Different Amendments and Nitrogen Application on Physico-Chemical and Biological Properties of Sodic Soil
}

\author{
T. Naveenkumar ${ }^{1}$, M. Baskar ${ }^{2 *}$, G. Gomadhi ${ }^{1}$, \\ K. Sivasubramanian ${ }^{3}$ and P. Balasubramaniam ${ }^{1}$
}

\author{
${ }^{1}$ Department of Soil Science and Agricultural Chemistry, Anbil Dharmalingam Agricultural \\ College and Research Insistute, Trichy, Tamilnadu, India \\ ${ }^{2}$ Institute of Agriculture, AEC \& RI, Kumulur, Trichy, Tamilnadu, India \\ ${ }^{3}$ Department of Environmental Science, TNAU, Coimbatore, Tamilnadu, India
}

*Corresponding author

\section{Keywords}

Sodic soil, Gypsum,

Green manure,

Green leaf manure,

Distillery spent

wash, Nitrogen,

Physico-chemical

properties,

Biological

properties

Article Info

Accepted:

18 May 2019

Available Online:

10 June 2019

\section{A B S T R A C T}

Currently more than 20 per cent of the world's irrigated land is salt affected. Of that about 60 per cent are sodic soils, warranting attention for efficient, inexpensive and environmentally feasible amelioration. An incubation study was performed to study the influence of amendments on physico-chemical and biological properties of sodic soil. Gypsum + Green manure @6.5 t ha ${ }^{-1}$, Distillery spentwash (DSW)@ 5 lakhs liter ${ }^{-1}$, Green leaf manure (GLM) @ $12.5 \mathrm{t} \mathrm{ha}^{-1}$ were used as amendments for the reclamation of sodic soil by adopting standardized reclamation procedure. The results of the incubation study revealed that application of amendments decreased the $\mathrm{pH}$ of the soil. The $\mathrm{pH}$ declined from the initial level of 10.2 to 8.37, 8.42 and 9.21due to application of DSW, Gypsum + GM, and GLM respectively. Maximum reduction in soil $\mathrm{pH}$ was recorded in DSW applied treatments. The soluble salt concentration was found to be slightly increased in the DSW applied treatments, but the extent of increase was within the permissible limit $\left(<4 \mathrm{dS} \mathrm{m}^{-1}\right)$. Soil ESP was significantly reduced on reclamation to the level of 13.1, 13.5 and 24.2 per cent on account of application of DSW, Gypsum + GM, and Green leaf manure respectively from the initial level of 31.8 per cent with increased exchangeable $\mathrm{Ca}, \mathrm{Mg}$ and $\mathrm{K}$ and reduced exchangeable $\mathrm{Na}$ content of the soil. The application of amendments significantly improved microbial population and soil enzyme activity of the soil in the order of DSW $>$ Gypsum + GM $>$ GLM $>$ control.

\section{Introduction}

Sodic soils are exhibiting poor physical and chemical properties, which impede water infiltration, water availability and ultimately plant growth. In India nearly 6.73 million hectare area is salt affected and out of that
3.77 million hectare of land is affected by sodic soil. Tamil Nadu alone has 3.5 lakh hectares of sodic soil. Large extent of land in India is affected by sodicity due to major degradation processes like sodification, water logging, chemical impairment and desertification (Dagar and Singh, 1994). In 
order to overcome sodicity different amendments were used based on its availability and cost which favourabley improved the physic-chemical and biological properties of sodic soil.

Reclamation of sodic soils are normally achieved by supplementing readily available calcium $\left(\mathrm{Ca}^{2+}\right)$ sources to replace the excess $\mathrm{Na}^{+}$on the exchange complex and leaching the displaced $\mathrm{Na}^{+}$from the root zone through excess irrigation water with better drainage facilities. Amelioration of these soils has been predominantly achieved through the application of chemical amendments. However increasing cost of chemical amendments and recurrent sodicity issues necessitated the identification of alternative low cost approaches to sustain the productivity of these soils.

Gypsum, distillery spent wash, green manures and green leaf manures are widely used for reclamation (Davies et al., 2011). Hence effective utilization of distillery spent wash, gypsum, green manure and Green leaf manure on reclamation of sodicity was assessed to improve the soil physico chemical and biological properties. Sustainable farming in sodic soil and increased food production.

\section{Materials and Methods}

The soil used for incubation experiment was clay loam in texture belongs to Madukhur series. The incubation experiment having eight treatments with three replications. The experiment was laid out in CRD with the treatments includes control $\left(\mathrm{T}_{1}\right)$,gypsum + green manure@6.25 t ha ${ }^{-1}\left(\mathrm{~T}_{2}\right)$, green leaf manure@12.5 t ha ${ }^{-1}\left(\mathrm{~T}_{3}\right)$, Distillery spent wash@ @lakh liters ha ${ }^{-1}\left(\mathrm{~T}_{4}\right)$, Nitrogen alone @ $75 \mathrm{~kg} \mathrm{ha}^{-1}\left(\mathrm{~T}_{5}\right)$, Gypsum + Green manure @6.25 t ha ${ }^{-1}+$ Nitrogen@ $75 \mathrm{~kg} \mathrm{ha}^{-1}\left(\mathrm{~T}_{6}\right)$, Green leafmanure@12.5 tha ${ }^{-1}+$ Nitrogen@
$75 \mathrm{~kg} \mathrm{ha}^{-1}\left(\mathrm{~T}_{7}\right)$, DSW @5 lakh liters ha ${ }^{-1}+$ Nitrogen@75 kg ha ${ }^{-1}\left(\mathrm{~T}_{8}\right)$.

The soils were incubated at saturated condition for 60days and were analysed for pysico- chemical properties viz, Exchangeable $\mathrm{Ca}, \mathrm{Mg}$, $\mathrm{Na}$, and $\mathrm{K}$, ESP and biological properties viz., Bacteria, Fungai, Actinomycetes, Dehydrogenase activity, Urease activity, and Phosphatase activity.

\section{Results and Discussion}

\section{Characteristics of the initial soil}

The incubation experiment was carried out on Madukhur soil series at AEC \&RI, Kumulur. The soil was clay loam in texture with a bulk density, particle density and porosity of 1.2 $\mathrm{Mg} \mathrm{m}^{-3}, 2.22 \mathrm{Mg} \mathrm{m}^{-3}$ and 58.60 per cent respectively. The experimental soil washighly sodic ( $\mathrm{pH} 10.2)$, low in EC $\left(0.72 \mathrm{dS} \mathrm{m}^{-1}\right)$. The soilorganic carbon was $0.48 \%$ The Exchangable $\mathrm{Ca}, \mathrm{Mg}, \mathrm{Na}, \mathrm{K}$ and ESP were6.21 $\mathrm{cmol}(\mathrm{p}+) \mathrm{kg}^{-1}, 4.81 \mathrm{cmol}(\mathrm{p}+) \mathrm{kg}^{-1}$, $5.12 \mathrm{cmol}(\mathrm{p}+) \mathrm{kg}^{-1}, 0.08 \mathrm{cmol}(\mathrm{p}+) \mathrm{kg}^{-1}$ and 31.8 respectively.

\section{Effect of Soil pH and EC:}

Soil physical, chemical and biological properties are directly related with $\mathrm{pH}$. The soils without amendment registered highest $\mathrm{pH}$ of 10.2. In sodic soils, reaction of exchangeable sodium and $\mathrm{CaCO}_{3}$ under low $\mathrm{CO}_{2}$ conditions lead to higher concentration of sodium carbonate and consequently increased the soil $\mathrm{pH}$ (Cruz-Romero and Coleman, 1975). The application of amendments significantly reduced the $\mathrm{pH}$. The maximum reduction in $\mathrm{pH}$ was recorded in the DSW applied treatments followed by Gypsum + GM and GLM.

This reduction in $\mathrm{pH}$ on application of DSW was due to several reasons. The acidic nature 
(pH 4.3) of DSW which directly contributes to the $\mathrm{pH}$ reduction. Because of the acidic nature of $\mathrm{DSW}$, the free lime may be solubilized in soil and releasing $\mathrm{Ca}$ ions. The $\mathrm{Ca}$ ions replaces $\mathrm{Na}$ ions and forms soluble sodium salts which get leached out during leaching. The reduction in $\mathrm{pH}$ might also be due to $\mathrm{Ca}$ supplied directly by the DSW. Similar reduction in $\mathrm{pH}$ was reported by Mohamed Harron and Subash Chandra Bose (2004) for calcareous sodic soils of Tiruchirapalli,

The reduction in soil $\mathrm{pH}$ on application of Gypsum + GM was attributed to the displacement of exchangeable $\mathrm{Na}$ by the calcium ions of gypsum and subsequent formation of sodium sulphate which get leached out due to drainage provided. The addition of GM after gypsum leads to further reduction in $\mathrm{pH}$ by producing organic acids during decomposition which solubilizes the native $\mathrm{Ca}$. Application of GLM had ameliorative effect and reduced the soil $\mathrm{pH}$ due to liberation of $\mathrm{CO}_{2}$ and organic acids during decomposition process and produces hydrogen ions which solubilize the $\mathrm{CaCO}_{3}$ and neutralize the sodicity. Similar results were observed by Pattanayak et al., (2001), Yaduvanshi (2001) and Smiciklas et al., (2002) where they observed a decrease in soil $\mathrm{pH}$ after the use of organic materials.

The application of distillery spent wash (DSW) had slightly increased the electrical conductivity of soils. This was due to high salt content in raw spent wash added to soils during reclamation process, resulting in slight salt build-up even though drainage was provided to these treatments. There was no reduction in EC in Gypsum + GM applied treatments which might be due to very low solubility of gypsum $\left(2.8 \mathrm{~g} \mathrm{~L}^{-1}\right)$ but there was a slight increase in EC in the GLM applied treatments and Gypsum + GM treatments due to increase in amount of soluble salts.

\section{Effect on soil exchangeable cations}

Application of amendments had a significant influence on the exchangeable cations of incubated soil especially the beneficial cations viz., $\mathrm{Ca}, \mathrm{Mg}$ and $\mathrm{K}$. The changes in the concentration of exchangeable cations on application of DSW were significant.

\section{Exchangeable calcium}

The exchangeable calcium content of soil was found in the range of 6.24 to $8.86 \mathrm{cmol}(\mathrm{p}+)$ $\mathrm{kg}^{-1}$ (Table 1). The exchangeable calcium content of the incubated soil after $60^{\text {th }}$ day was significantly increased due to application of amendments. The acidic nature of distillery spent wash might have solubilized some native free lime as well as small quantity of dolomitic lime which have released $\mathrm{Ca}+\mathrm{Mg}$ in free ionic forms that might have also contributed for increased $\mathrm{Ca}$ on exchange sites by replacing exchangeable Na. Similar observations were reported by Mahimaraja and Bolan (2000). The application of raw spent wash increased the Ca contents was also reported by Baskar et al., (2003).

The increase in calcium in the Gypsum + GM applied treatments was mainly due to calcium ions from gypsum $\left(\mathrm{CaSO}_{4} \cdot 2 \mathrm{H}_{2} \mathrm{O}\right)$. In addition, the solublization of native calcium on decomposition of green manure incorporated in the fields also contributed $\mathrm{Ca}$. The exchangeable $\mathrm{Ca}$ content was on par with DSW applied treatments due to high amounts of Ca present in gypsum. Application GLM also considerably increased the exchangeable calcium content. This might be due to the positive effect of organic substance on improving sodic soil. The release of $\mathrm{CO}_{2}$ during the degradation process decreased the precipitation of $\mathrm{Ca}^{2+}$ and $\mathrm{CO}_{3}{ }^{2-}$ ions in the $\mathrm{CaCO}_{3}$ form (Sekhonand Bejawa, 1993). On the other hand, the organic acids released the $\mathrm{Ca}$ from $\mathrm{CaCO}_{3}$. 
Table.1 Influence of different amendments and nitrogen on physico-chemical properties of Sodic soil

\begin{tabular}{|c|c|c|c|c|c|c|c|}
\hline & \multirow[t]{2}{*}{ pH } & \multirow{2}{*}{$\underset{\left(d^{S S m} m^{-1}\right)}{E C}$} & $\mathbf{C a}$ & Mg & K & $\mathbf{N a}$ & \multirow{2}{*}{$\begin{array}{l}\text { ESP } \\
(\%)\end{array}$} \\
\hline & & & \multicolumn{4}{|c|}{$\operatorname{cmol}\left(p^{+}\right) \mathbf{k g}^{-1}$} & \\
\hline T1 & 10.2 & 0.74 & 6.24 & 4.83 & 0.08 & 5.12 & 31.8 \\
\hline T2 & 8.45 & 0.76 & 8.86 & 5.12 & 0.12 & 2.16 & 13.5 \\
\hline T3 & 9.25 & 0.75 & 7.1 & 5.24 & 0.12 & 4.01 & 24.2 \\
\hline T4 & 8.38 & 1.18 & 8.2 & 5.1 & 0.92 & 2.14 & 13.2 \\
\hline T5 & 10.1 & 0.76 & 6.45 & 4.84 & 0.09 & 5.21 & 30.8 \\
\hline T6 & 8.42 & 0.65 & 8.81 & 5.08 & 0.1 & 2.17 & 13.9 \\
\hline T7 & 9.21 & 0.78 & 7.12 & 5.21 & 0.12 & 4.15 & 24.5 \\
\hline T8 & 8.37 & 1.20 & 7.84 & 5.35 & 0.96 & 2.17 & 13.1 \\
\hline SE(d) & 0.20 & 0.01 & 0.12 & 0.10 & 0.008 & 0.08 & 0.36 \\
\hline CD 5\% & 0.44 & 0.02 & 0.26 & 0.21 & 0.018 & 0.17 & 0.77 \\
\hline
\end{tabular}

Table. 2 Correlation between different physico-chemical properties of sodic soil

\begin{tabular}{|c|c|c|c|c|c|}
\hline & \multirow[t]{2}{*}{ pH } & Exch. Na & Exch. Ca & Exch. Mg & \multirow{2}{*}{$\begin{array}{l}\text { ESP } \\
(\%)\end{array}$} \\
\hline & & \multicolumn{3}{|c|}{$\operatorname{cmol}\left(\mathrm{p}^{+}\right) \mathrm{kg}^{-1}$} & \\
\hline pH & 1 & & & & \\
\hline $\begin{array}{c}\text { Exchangeable } \\
\mathrm{Na}\end{array}$ & $0.96^{*}$ & 1 & & & \\
\hline $\begin{array}{c}\text { Exchangeable } \\
\text { Ca }\end{array}$ & $-0.92 *$ & $-0.94 *$ & 1 & & \\
\hline $\begin{array}{c}\text { Exchangeable } \\
\text { Mg }\end{array}$ & -0.75 & -0.61 & 0.47 & 1 & \\
\hline ESP & $0.96 *$ & 1.00 & $-0.94 *$ & -0.62 & 1 \\
\hline
\end{tabular}

Table.3 Influence of different amendments and nitrogen on microbial population of sodic soil

\begin{tabular}{|c|c|c|c|}
\hline & $\begin{array}{c}\text { Bacteria } \\
\left(\times \mathbf{1 0}^{\mathbf{5}} \mathbf{C F U} \mathbf{~ g}^{-\mathbf{1}} \mathbf{~ o f ~ s o i l ~}\right)\end{array}$ & $\begin{array}{c}\text { Fungi } \\
\left(\times \mathbf{1 0}^{\mathbf{2}} \mathbf{C F U} \mathbf{~ g}^{-\mathbf{1}} \mathbf{~ o f ~ s o i l ~}\right)\end{array}$ & $\begin{array}{c}\text { Actinomycetes } \\
\left(\times \mathbf{1 0}^{\mathbf{3}} \mathbf{C F U} \mathbf{~}^{-\mathbf{1}} \text { of soil }\right)\end{array}$ \\
\hline T1 & 12.4 & 2.8 & 1.2 \\
\hline T2 & 13.8 & 3.4 & 1.8 \\
\hline T3 & 15.2 & 3.9 & 2.4 \\
\hline T4 & 16.3 & 4.4 & 2.9 \\
\hline T5 & 12.9 & 2.9 & 1.4 \\
\hline T6 & 14.2 & 3.7 & 2.3 \\
\hline T7 & 15.6 & 4.2 & 2.9 \\
\hline T8 & 16.8 & 4.7 & 3.2 \\
\hline SE(d) & 0.27 & 0.07 & 0.05 \\
\hline CD 5\% & 0.57 & 0.16 & 0.11 \\
\hline
\end{tabular}


Table.4 Influence of different amendments and nitrogen on soil enzyme activites of sodic soil

\begin{tabular}{|c|c|c|c|}
\hline & $\begin{array}{l}\text { Dehydrogenase } \\
\left(\mu \mathrm{g} \text { TPF } \mathrm{g}^{-1} \mathrm{hr}^{-1}\right)\end{array}$ & $\begin{array}{c}\text { Urease } \\
\left(\mu \mathrm{g} \mathrm{NH}-\mathrm{N} \mathrm{g}^{-1} \mathrm{hr}^{-1}\right)\end{array}$ & $\begin{array}{c}\text { Phosphates } \\
\left(\mu \mathrm{g} \text { nitrophenol } \mathrm{g}^{-1} \mathrm{hr}^{-1}\right)\end{array}$ \\
\hline T1 & 1.12 & 1.36 & 4.14 \\
\hline T2 & 1.46 & 1.59 & 5.1 \\
\hline T3 & 1.54 & 1.95 & 6.21 \\
\hline T4 & 1.59 & 2.01 & 6.75 \\
\hline T5 & 1.16 & 1.39 & 4.31 \\
\hline T6 & 1.51 & 1.65 & 5.48 \\
\hline T7 & 1.58 & 1.98 & 6.35 \\
\hline T8 & 1.61 & 2.18 & 6.81 \\
\hline $\operatorname{SE}(d)$ & 0.03 & 0.03 & 0.13 \\
\hline CD 5\% & 0.07 & 0.07 & 0.28 \\
\hline
\end{tabular}

Fig.1 Interaction between soil pH and ESP as influenced by different amendments and levels of $\mathrm{N}$ application

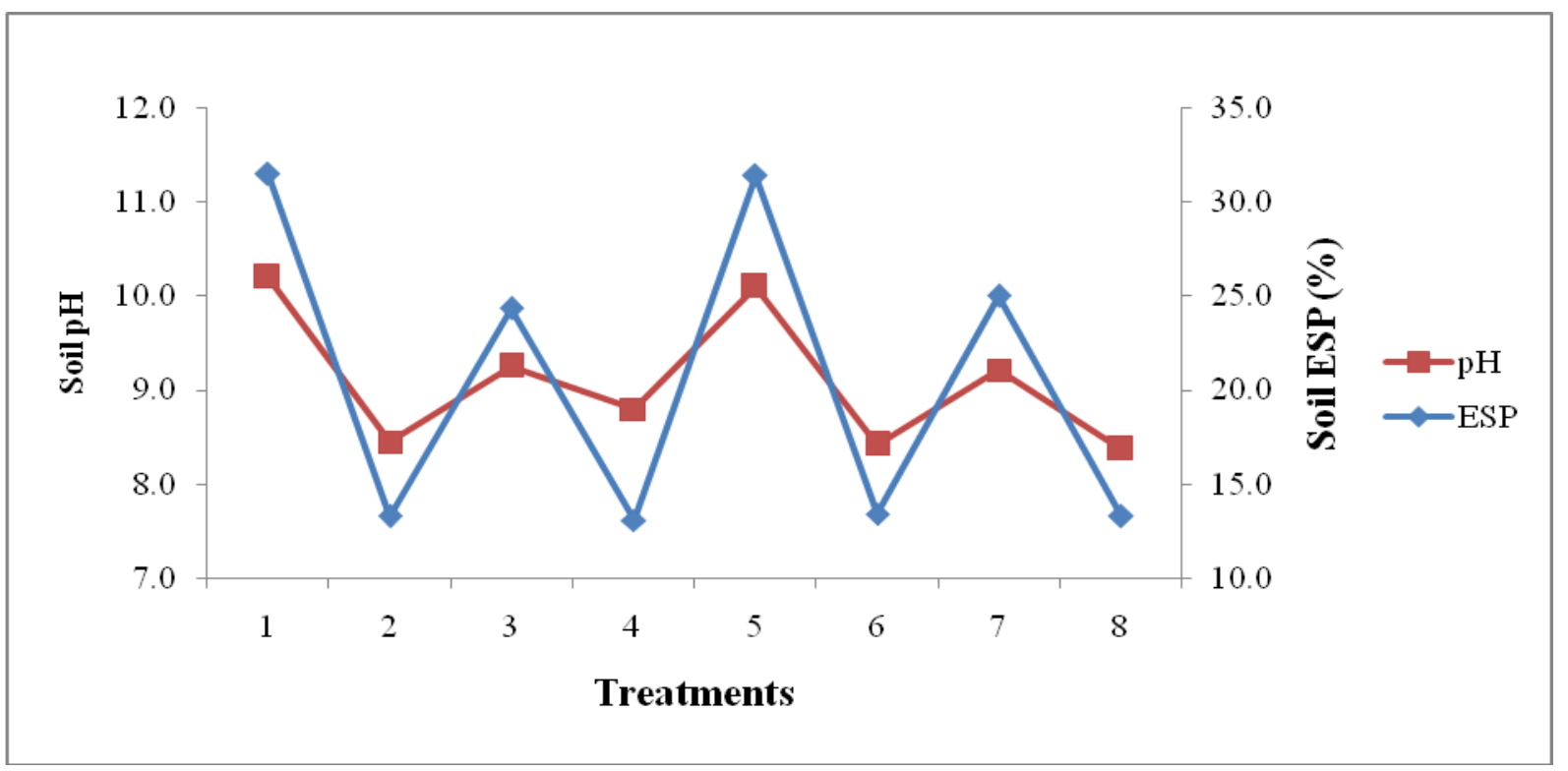

\section{Exchangeable Magnesium}

A significant increase in the exchangeable $\mathrm{Mg}$ content of the incubated soil after $60^{\text {th }}$ day was enrolled on application of amendments. Increase in exchangeable $\mathrm{Mg}$ content (5.35 $\left.\mathrm{cmol}(\mathrm{p}+) \mathrm{kg}^{-1}\right)$ after application of distillery spent wash (Table 1) was attributed to direct contribution and also due to the solubilization of small quantity of dolomitic lime which have released $\mathrm{Ca}+\mathrm{Mg}$ in free ionic forms that might have also contributed for increased $\mathrm{Mg}$ on exchange sites. This was in line with Mahimaraja and Bolan (2000) and Baskar et al., (2003). The increase in $\mathrm{Ca}$ and $\mathrm{Mg}$ in the Gypsum + GM applied treatments was mainly due to reduction in $\mathrm{pH}$ of soil and solubilization of native calcium and magnesium ions on decomposition of green manure incorporated in the fields. The tendency of the DSW to increase the exchangeable $\mathrm{Ca}$ and $\mathrm{Mg}$ was also reported 
by Cepro and Machado (1987) and Thitakamol and Kaewpinthong (2007).

\section{Exchangable potassium}

The exchangeable potassium $(\mathrm{K})$ content of the incubated soil at $60^{\text {th }}$ day ranged from

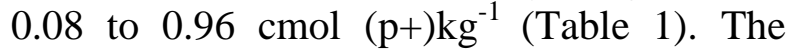
influence of amendments significantly maximized the exchangeable Kcontent of the soil. Among the different amendments, DSW @5 lakh liters ha ${ }^{-1}+$ Nitrogen @ 75 kg ha ${ }^{1}$ showed highest exchangeable $\mathrm{K}$ content of $0.96 \mathrm{cmol} \quad(\mathrm{p}+) \mathrm{kg}^{-1}$ followed by 0.92 cmol(p+) $\mathrm{kg}^{-1}$ (Table 1) in DSW@ 5lakh liters $\mathrm{ha}^{-1}, 0.12 \mathrm{cmol}(\mathrm{p}+) \mathrm{kg}^{-1}$ in gypsum + green manure@6.25 tha ${ }^{-1}$ and green leaf manure @ $12.5 \mathrm{t} \mathrm{ha}^{-1}$ application and lowest value of $0.08 \mathrm{cmol}(\mathrm{p}+) \mathrm{kg}^{-1}$ was registered in the control. In DSW applied treatments, the quantity of increase in exchangeable $\mathrm{K}$ was higher due to enomorus supply of $\mathrm{K}$ from DSW. In Gypsum and GM incubated soil exchangeable $\mathrm{K}$ increased due to replacement of $\mathrm{Na}$ (Abdel Fattah, 2012). The GM and GLM also contributes considerable amount of $\mathrm{K}$ to the soil since it contains a good amount of $\mathrm{K}(1.8 \%)$.

\section{Exchangable Sodium}

The data on the exchangeable sodium $(\mathrm{Na})$ content showed that the values ranged between 2.14 and $5.21 \mathrm{cmol}(\mathrm{p}+) \mathrm{kg}^{-1}$ (Table 1). The application of amendments showed a highly significant decline in the exchangeable $\mathrm{Na}$ content of soil. The lowest exchangeable $\mathrm{Na}$ content of $2.14 \mathrm{cmol}(\mathrm{p}+) \mathrm{kg}^{-1}$ and highest exchangeable $\mathrm{Na}$ content of $5.21 \mathrm{cmol}(\mathrm{p}+)$ $\mathrm{kg}^{-1}$ (Table 1) was observed in DSW and the $\mathrm{N}$ application without amendments respectively

The greatest decrease in exchangeable $\mathrm{Na}$ in DSW applied treatments was because of greater solubilization of free lime by the acidic nature of raw spent wash that released adequate $\mathrm{Ca}$ which is sufficient enough to replace exchangeable Na. Similar observation was also reported by Mohammed Harron and Subash Chandra Bose (2004) for calcareous soils in Tamil Nadu.

In Gypsum + GM applied treatments, the reduction in exchangeable $\mathrm{Na}$ was attributed to replacement of exchangeable $\mathrm{Na}$ by $\mathrm{Ca}$ present in gypsum and dissolution of free lime on decomposition of GM applied along with gypsum. The present findings are in agreement with the findings of Moustafa (2005). In GLM applied treatments also exchangeable $\mathrm{Na}$ was reduced to considerable amount due to replacement by $\mathrm{Ca}$ released to the soil solution by the action of organic acids and also the direct contribution of $\mathrm{Ca}$ from organics. The exchangeable sodium and $\mathrm{pH}$ was highly correlated with the $\mathrm{R}^{2}$ value of 0.96 (Table 2).

\section{Exchangeable sodium percentage}

The relative amounts of exchangeable sodium in comparison with the total cations in the soil exchange complex are dependent on factors, such as type of minerals, concentration of electrolytes and status of soluble cations (Sehgal et al., 1968).The exchangeable sodium percent of the incubated soils after $60^{\text {th }}$ day were greatly reduced due to DSW application. The exchangeable sodium percentage decreased from the initial level of 31.8 to $13.2,13.5$ and 24.2 due to application of DSW, Gypsum + GM and GLM respectively. The highest ESP was observed in control and the lowest ESP percentage was observed in treatment DSW @5 lakh liters $\mathrm{ha}^{-1}+$ Nitrogen@75 kg ha ${ }^{-1}\left(\mathrm{~T}_{8}\right)$ (Fig. 1; Table 1). The decreased trends follows for the application of different amendments were DSW, Gypsum + Greenmanure and Greenleaf manure respectively. This might be due to increase in beneficial cations viz., $\mathrm{Ca}, \mathrm{Mg}$ and 
$\mathrm{K}$ in exchangeable complex. The ESP and $\mathrm{pH}$ was positively correlated with the $\mathrm{R}^{2}$ value of 0.96 (Table 2).

\section{Effect on biological properties}

\section{Soil microbial population}

Microbial activity had a direct impact on the plant nutrient availability as well as other properties related to soil productivity. The soil microbial population viz, bacteria, fungi, and actinomycetes were significantly improved due to application of different amendments. The bacterial population ranged between 12.4 and $16.8 \times 10^{5} \mathrm{CFU} \mathrm{g}^{-1}$ (Table 3 ) of soil. The highest bacterial population was observed in DSW@5 lakh liters ha ${ }^{-1}+$ Nitrogen@ $975 \mathrm{~kg}$ $\mathrm{ha}^{-1}\left(\mathrm{~T}_{8}\right)$. The lowest fungi population was observed in control $\left(2.8 \times 10^{2} \mathrm{CFU} \mathrm{g}^{-1}\right.$ of soil $)$ and highest population of fungi was observed in the treatment which received DSW @5 lakh liters $\mathrm{ha}^{-1}+$ Nitrogen@ $975 \mathrm{~kg} \mathrm{ha}^{-1}\left(\mathrm{~T}_{8}\right)$. The population of actinomycetes ranged from 1.2 , to $3.2 \times 10^{3} \mathrm{CFU} \mathrm{g}^{-1}$ (Table 3 ) in control and DSW @5 lakh liters ha ${ }^{-1}+$ Nitrogen@ 97 $\mathrm{kg} \mathrm{ha}{ }^{-1}\left(\mathrm{~T}_{8}\right)$ respectively. Being rich in nutrients and organic material, particularly easily oxidizable and soluble organic carbon, the DSW might have favoured the proliferation of microbial population throughout the crop growth by the steady supply of nutrients and buildup of organic matter in soils. This was in line with the findings of Maheswari (2011).

\section{Soil enzyme activities}

Enzyme activity in soil is an indirect indication of the microbial activity, which is directly correlated with soil microbial population. Dehydrogenases are considered to play an essential role in initial stages of the oxidation of soil organic matter by transferring hydrogen and electrons from substrates to acceptors. Remarkable improvement in the dehydrogenase activity was observed due to application of amendments. The activities of dehydrogenase enzyme varied between 1.12 and $1.61 \mu \mathrm{g}$ TPF $\mathrm{g}^{-1} \mathrm{hr}^{-1}$, minimum (1.12 $\mu \mathrm{g}$ TPF $\left.\mathrm{g}^{-1} \mathrm{hr}^{-1}\right)$ (Table 4) being observed in control $\left(\mathrm{T}_{1}\right)$ and the maximum $\left(1.61 \mu \mathrm{g}\right.$ TPF $\left.\mathrm{g}^{-1} \mathrm{hr}^{-1}\right)$ in soil with the application of DSW @5 lakh liters $\mathrm{ha}^{-1}+$ Nitrogen@ $75 \mathrm{~kg} \mathrm{ha}^{-1}\left(\mathrm{~T}_{8}\right)$. Ramana et al., (2002) also reported that the enzyme activities were increased due to the application of distillery effluent.

The enzyme urease was associated with $\mathrm{N}$ mineralization. Urease activity in the incubated soil ranged from 1.36 to $2.18 \mu \mathrm{g}$ $\mathrm{NH}_{4}-\mathrm{N} \mathrm{g}^{-1} \mathrm{hr}^{-1}$ (Table 4). The treatment which received of DSW @5 lakh liters $\mathrm{ha}^{-1}+$ Nitrogen@75 kg ha ${ }^{-1}\left(\mathrm{~T}_{8}\right)$ recorded highest urease activity $\left(2.18 \mu \mathrm{g} \quad \mathrm{NH}_{4}-\mathrm{N} \quad \mathrm{g}^{-1} \mathrm{hr}^{-1}\right)$ (Table 4) followed by DSW@ 5lakh liters ha ${ }^{-}$ ${ }^{1}\left(\mathrm{~T}_{4}\right)$. The phosphatases hydrolyze organic $\mathrm{P}$ to inorganic $\mathrm{P}$, catalyze the rate limiting steps of $\mathrm{P}$ nutrient cycling and therefore, phosphatase activity plays a significant role in $\mathrm{P}$ availability to plants from native organic $\mathrm{P}$ compounds. The phosphatase activity ranged between 4.14 to $6.81 \mu \mathrm{g}$ nitrophenol $\mathrm{g}^{-1} \mathrm{hr}^{-1}$. An increase in phosphatase activity was observed due to application of DSW @5 lakh liters ha ${ }^{-1}+$ Nitrogen@ $75 \mathrm{~kg} \mathrm{ha}^{-1}\left(\mathrm{~T}_{8}\right)$.

\section{References}

Abdel-Fattah Mohamed. 2012. Role of gypsum and compost in reclaiming saline-sodic soils. J. Agric. Vet. Sci., 1: 30-38.

Baskar, M., C. Kayalvizhi and M. Subash Chandra Bose. 2003. Ecofriendly utilization of distillery effluent in agriculture - A Review. Agricultural Reviews, 24: 16-30.

Cepro, G.S. and A.J. Machado. 1987. Centro Agric. 14(4): 76-80.

Cruz-romero, G. and N.T. Coleman. 1975. 
Reactions responsible for high $\mathrm{pH}$ of $\mathrm{Na}$ saturated soils and clays. J. Soil Sci., 26: 169-175.

Dagar, J.C. and N.T. Singh. 1994. Agroforestry options in the reclamation of problem soils. In: Tree and tree farming, Peekay Tree Crops Development Foundation, Cochin, pp. 63-103.

Davies, P. A., Hossain, A. K., Igobo, O. N., Garantziotis, G., Srivastava, R., and Kaphaliya, B. 2011. A greenhouse integrating desalination, water saving and rainwater harvesting for use in salt affected inland regions, J. Scient. Indust. Res., 70, 628-633,

Maheswari, K. 2011. Eco-friendly and effective nitrogen management with treated distillery effluent and its impact on rice yield and soil properties. M. Sc., Thesis, Tamil Nadu Agricultural University, Coimbatore.

Mahimairaja and S. Bolan. 2000. Third Australian New Zealand Soils Conference, 5-9 December 2000, University of Sydney, Australia.

Mohamed Haroon, A. R. and Subash Chandra Bose, M. 2004. Use of distillery spentwash for alkali soil reclamation, treated distillery effluent for fertigation of crops. Indian Farm, 48-51.

Moustafa, F.A.F. 2005. Studies on reclamation of saline sodic soils. Ph.D thesis, Benha Univ., Egypt, pp.35-60.

Patil, G. D., S. M. Pingat and Yelwande. 2000. Effect of spentwash levels on soil fertility, uptake, quality and yield of Fodder Maize. J. Maharashtra Agri. Univ., 25: 168-170.
Pattanayak, S. K., K. N. Mishra, M. K. Jena and R. K. Nayak. 2001. Evaluation of green manure crops fertilized with various phosphorus sources and their effect on subsequent rice crop. $J$. Indian. Soc. Soil Sci., 49: 285-291.

Ramana, S., A. K. Biswas and A.B Singh. 2002. Effect of distillery effluents on some physiological aspects in maize. Bioresource Technol., 84: 295-297.

Sehgal, J. L., D.R. Bhumla and D.R. Dhingza. 1968. Soils of the Sutlej and flood basin areas in the Punjab. J. Indian Soc. Soil Sci., 6: 241-247.

Sharma, D.R., P.S. Minhas and D.K. Sharma. 2001. Response of Rice-Wheat to sodic water irrigation and gypsum application. J. Indian Soc. Soil Sci., 49: 324-327.

Smiciklas, K. D., P. M. Alker and T. R. Kelley. 2002. Utilization of compost (Food, Paper, Landscape and Manure) in Row Crop production. Department of Agriculture and Health Sciences, Illinois state University, USA.

Thitakamol, T. and S. Kaewpinthong. 2004. Utilization of distillery slop for the rice production in Khonkaen province. In: Research report submitted to National Research Council of Thailand. Bangkok, Thailand. pp. 23-56.

Yaduvanshi, N. P. S. 2001. Effect of five years of rice-wheat cropping an NPK fertilizer use with and without organic and green manures on soil properties and crop yields in a reclaimed sodic soil. J. Indian Soc. Soil Sci., 49: 714719.

\section{How to cite this article:}

Naveenkumar, T., M. Baskar, G. Gomadhi, K. Sivasubramanian and Balasubramaniam, P. 2019. Effects of Different Amendments and Nitrogen Application on Physico-Chemical and Biological Properties of Sodic Soil. Int.J.Curr.Microbiol.App.Sci. 8(06): 3028-3035. doi: https://doi.org/10.20546/ijcmas.2019.806.361 